\title{
Ruthenium-mediated reduction of oximes to imines. Synthesis, characterization and redox properties of imine complexes of ruthenium
}

\author{
Anjan Kumar Das, ${ }^{a}$ Shie-Ming Peng ${ }^{b}$ and Samaresh Bhattacharya *a \\ ${ }^{a}$ Department of Chemistry, Inorganic Chemistry Section, Jadavpur University, \\ Calcutta 700 032, India \\ ${ }^{b}$ Department of Chemistry, National Taiwan University, Taipei, Taiwan, Republic of China
}

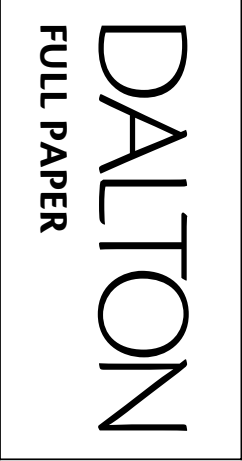

\section{Received 31st August 1999, Accepted 15th November 1999}

Reaction of three oxime ligands (oximes of salicylaldehyde $\left(\mathrm{HL}^{1}-\mathrm{O}\right), 2$-hydroxyacetophenone $\left(\mathrm{HL}^{2}-\mathrm{O}\right)$ and 2-hydroxynaphthylaldehyde $\left(\mathrm{HL}^{3}-\mathrm{O}\right)$; where $\mathrm{H}$ stands for the phenolic proton and $\mathrm{O}$ for the oxime oxygen) with $\left[\mathrm{Ru}\left(\mathrm{PPh}_{3}\right)_{3} \mathrm{Cl}_{2}\right]$ in a 1:1 molar ratio brings about reduction of the oximes to imines and affords complexes of the form $\left[\mathrm{Ru}\left(\mathrm{PPh}_{3}\right)_{2}(\mathrm{~L}) \mathrm{Cl}_{2}\right]$, where $\mathrm{L}$ stands for the deprotonated imine ligand which is coordinated as a $N, O$-donor forming a six-membered chelate ring. The structure of the $\left[\mathrm{Ru}\left(\mathrm{PPh}_{3}\right)_{2}\left(\mathrm{~L}^{2}\right) \mathrm{Cl}_{2}\right]$ complex has been solved by X-ray crystallography. The coordination sphere around ruthenium is composed of $\mathrm{NOP}_{2} \mathrm{Cl}_{2}$ with the two $\mathrm{PPh}_{3}$ ligands in mutually trans and the two chlorides in mutually cis positions. The $\left[\mathrm{Ru}\left(\mathrm{PPh}_{3}\right)_{2}(\mathrm{~L}) \mathrm{Cl}_{2}\right]$ complexes are one-electron paramagnetic (low-spin $\mathrm{d}^{5}, S=1 / 2$ ) and show rhombic EPR spectra in 1:1 dichloromethane-toluene solution at $77 \mathrm{~K}$. In dichloromethane solution the $\left[\mathrm{Ru}\left(\mathrm{PPh}_{3}\right)_{2}(\mathrm{~L}) \mathrm{Cl}_{2}\right]$ complexes show several intense LMCT transitions in the visible region, together with a weak ligand field transition near $1700 \mathrm{~nm}$. Cyclic voltammetry on the $\left[\mathrm{Ru}\left(\mathrm{PPh}_{3}\right)_{2}(\mathrm{~L}) \mathrm{Cl}_{2}\right]$ complexes shows a ruthenium(III)-ruthenium(II) reduction near $-0.4 \mathrm{~V} v$ s. SCE and a ruthenium(III)-ruthenium(IV) oxidation in the range $0.88-1.15 \mathrm{~V} v$ s. SCE.

\section{Introduction}

Metal-promoted chemical transformation of organic molecules has been of significant current interest. ${ }^{1}$ Herein we wish to disclose an example of ruthenium-mediated reduction of oximes to imines (eqn. 1). It may be noted here that such reduction of

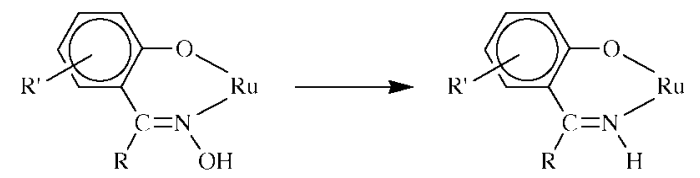

oximes to imines appears to be unusual. The ligands used in the present study are oximes of salicylaldehyde, 2-hydroxyacetophenone and 2-hydroxynaphthaldehyde. All these ligands are abbreviated in general as HL-O, where $\mathrm{H}$ stands for the dissociable phenolic proton and $\mathrm{O}$ for the oxime oxygen. Individual abbreviations are shown with structure $\mathbf{1}$. The ruthenium com-

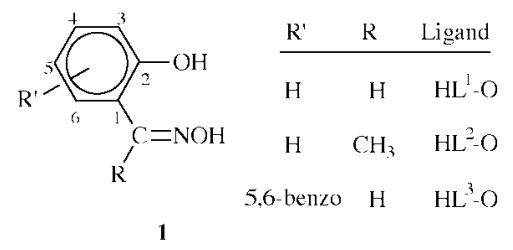

plex utilized for bringing about reduction of these oximes was $\left[\mathrm{Ru}\left(\mathrm{PPh}_{3}\right)_{3} \mathrm{Cl}_{2}\right]$. Reaction of the oximes with $\left[\mathrm{Ru}\left(\mathrm{PPh}_{3}\right)_{3} \mathrm{Cl}_{2}\right]$ afforded a group of complexes of the type $\left[\mathrm{Ru}\left(\mathrm{PPh}_{3}\right)_{2}(\mathrm{~L}) \mathrm{Cl}_{2}\right]$, where $\mathrm{L}$ stands for the deprotonated imine ligand. The chemistry of these complexes is described here with special reference to synthesis, characterization and redox properties.

\section{Experimental}

\section{Materials}

$\left[\mathrm{Ru}\left(\mathrm{PPh}_{3}\right)_{3} \mathrm{Cl}_{2}\right]$ was synthesized by following a literature method. $^{2}$ The oximes were prepared by reacting equimolar amounts of the respective aldehydes and hydroxylamine, following a reported procedure. ${ }^{3}$ Purification of dichloromethane and preparation of tetrabutylammonium perchlorate (TBAP) for electrochemical work was carried out as reported in the literature. $^{4}$

\section{Preparations}

[Ru(PPh $\left.\left.\left.)_{2}\right)_{2} \mathbf{L}^{1}\right) \mathbf{C l}_{2}\right]$. $\left[\mathrm{Ru}\left(\mathrm{PPh}_{3}\right)_{3} \mathrm{Cl}_{2}\right](100 \mathrm{mg}, 0.10 \mathrm{mmol})$ was refluxed with salicylaldoxime $(16 \mathrm{mg}, 0.11 \mathrm{mmol})$ in ethanol $\left(50 \mathrm{~cm}^{3}\right)$ for $2 \mathrm{~h}$. A green microcrystalline precipitate of [Ru$\left.\left(\mathrm{PPh}_{3}\right)_{2}\left(\mathrm{~L}^{1}\right) \mathrm{Cl}_{2}\right]$ started to separate out during the reflux. After cooling the solution to room temperature, the precipitate was collected by filtration, washed with ethanol and dried in air. Recrystallization from 1:4 dichloromethane-hexane gave $\left[\mathrm{Ru}\left(\mathrm{PPh}_{3}\right)_{2}\left(\mathrm{~L}^{1}\right) \mathrm{Cl}_{2}\right]$ as a green crystalline solid in $72 \%$ yield. Anal. Calc. for $\mathrm{C}_{43} \mathrm{H}_{35} \mathrm{NOCl}_{2} \mathrm{P}_{2} \mathrm{Ru}$ : C, 63.23; H, 4.41; N, 1.72 . Found: C, 63.30; H, 4.45; N, 1.73\%.

$\left[\mathbf{R u}\left(\mathbf{P P h}_{3}\right)_{2}\left(\mathbf{L}^{2}\right) \mathbf{C l}_{2}\right]$. This complex was prepared by following the same procedure as above, using the oxime of 2-hydroxyacetophenone $\left(\mathrm{HL}^{2}-\mathrm{O}\right)$ instead of salicylaldoxime. The yield was $70 \%$. Anal. Calc. for $\mathrm{C}_{44} \mathrm{H}_{38} \mathrm{NOCl}_{2} \mathrm{P}_{2} \mathrm{Ru}$ : C, 63.61; $\mathrm{H}, 4.58$; N, 1.69. Found: C, 63.66; H, 4.61; N, 1.70\%.

$\left[\mathbf{R u}\left(\mathbf{P P h}_{3}\right)_{2}\left(\mathbf{L}^{3}\right) \mathbf{C l}_{2}\right]$. This complex was prepared by following the same synthetic procedure as for $\left[\mathrm{Ru}\left(\mathrm{PPh}_{3}\right)_{2}\left(\mathrm{~L}^{1}\right) \mathrm{Cl}_{2}\right]$, using the oxime of 2-hydroxynaphthaldehyde $\left(\mathrm{HL}^{3}-\mathrm{O}\right)$ instead of salicylaldoxime. The yield was $70 \%$. Anal. Calc. for $\mathrm{C}_{47} \mathrm{H}_{37^{-}}$ $\mathrm{NOCl}_{2} \mathrm{P}_{2} \mathrm{Ru}: \mathrm{C}, 64.8 ; \mathrm{H}, 4.25 ; \mathrm{N}, 1.60$. Found: C, 64.24; H, 4.68; $\mathrm{N}, 1.69 \%$.

\section{Physical measurements}

Microanalyses $(\mathrm{C}, \mathrm{H}, \mathrm{N})$ were performed using a Perkin-Elmer $240 \mathrm{C}$ elemental analyzer. IR spectra were obtained on a PerkinElmer 783 spectrometer with samples prepared as $\mathrm{KBr}$ pellets. Electronic spectra were recorded on a Shimadzu UV 240 spectrophotometer. Magnetic susceptibilities were measured 
Table 1 Crystallographic data for $\left[\mathrm{Ru}\left(\mathrm{PPh}_{3}\right)_{2}\left(\mathrm{~L}^{2}\right) \mathrm{Cl}_{2}\right]$

\begin{tabular}{ll}
\hline Empirical formula & $\mathrm{C}_{44} \mathrm{H}_{38} \mathrm{NOP}_{2} \mathrm{Cl}_{2} \mathrm{Ru}$ \\
$f_{\mathrm{w}}$ & 830.7 \\
Space group & Monoclinic, $P 2_{1} / n$ \\
$a / \AA$ & $9.471(3)$ \\
$b / \AA$ & $23.981(3)$ \\
$c / \AA$ & $17.290(5)$ \\
$\beta /{ }^{\circ}$ & $97.23(3)$ \\
$V / \AA^{3}$ & $3895.8(17)$ \\
$Z$ & 4 \\
$\mathrm{Crystal}$ size/mm & $0.50 \times 0.50 \times 0.50$ \\
$T /{ }^{\circ} \mathrm{C}$ & 25 \\
$\mu / \mathrm{cm}^{-1}$ & 6.471 \\
$R_{\mathrm{f}}$ & $0.026^{a}$ \\
$R_{w}$ & $0.028^{b}$ \\
$\mathrm{GOF}$ & $2.75^{c}$ \\
${ }^{a} R_{\mathrm{f}}=\Sigma|| F_{\mathrm{o}}|-| F_{\mathrm{c}}|| / \Sigma\left|F_{\mathrm{o}}\right|$. & ${ }^{b} R_{w}=\left[\Sigma w\left(\left|F_{\mathrm{o}}\right|-\left|F_{\mathrm{c}}\right|\right)^{2} / \Sigma w\left(F_{\mathrm{o}}\right)^{2}\right]^{\frac{1}{2}}$. \\
$\left.\mid \Sigma w\left(\left|F_{\mathrm{o}}\right|-\mid F_{\mathrm{c}}\right)^{2} /(M-N)\right]^{\frac{1}{2}}$, where $M$ is the number of reflections and \\
$N$ is the number of parameters refined. \\
\hline
\end{tabular}

Table 2 Selected bond distances and bond angles for $\left[\mathrm{Ru}\left(\mathrm{PPh}_{3}\right)_{2}-\right.$ $\left.\left(\mathrm{L}^{2}\right) \mathrm{Cl}_{2}\right]$

\begin{tabular}{|c|c|c|c|}
\hline \multicolumn{2}{|c|}{ Bond distances/§̊ } & \multicolumn{2}{|l|}{ Bond angles $/^{\circ}$} \\
\hline $\mathrm{Ru}-\mathrm{Cll}$ & $2.3696(10)$ & $\mathrm{P} 1-\mathrm{Ru}-\mathrm{P} 2$ & $178.319(21)$ \\
\hline $\mathrm{Ru}-\mathrm{Cl} 2$ & $2.3718(9)$ & $\mathrm{Cl} 2-\mathrm{Ru}-\mathrm{N} 1$ & $174.53(6)$ \\
\hline $\mathrm{Ru}-\mathrm{P} 1$ & $2.4242(7)$ & $\mathrm{Cl1}-\mathrm{Ru}-\mathrm{O} 1$ & $172.34(5)$ \\
\hline $\mathrm{Ru}-\mathrm{P} 2$ & $2.4176(8)$ & $\mathrm{Cl} 1-\mathrm{Ru}-\mathrm{Cl} 2$ & $98.92(4)$ \\
\hline $\mathrm{Ru}-\mathrm{O} 1$ & $1.9687(15)$ & $\mathrm{O} 1-\mathrm{Ru}-\mathrm{N} 1$ & $86.36(7)$ \\
\hline $\mathrm{Ru}-\mathrm{N} 1$ & $2.0225(19)$ & & \\
\hline $\mathrm{O} 1-\mathrm{C} 1$ & $1.319(3)$ & & \\
\hline N1-C7 & $1.298(3)$ & & \\
\hline
\end{tabular}

using a PAR 155 vibrating sample magnetometer. EPR spectra were recorded on a Varian Model 109C E-line X-band spectrometer fitted with a quartz Dewar for measurements at $77 \mathrm{~K}$ (liquid dinitrogen). All spectra were calibrated against the spectrum of DPPH $(g=2.0037)$. Electrochemical measurements were made using a PAR model 273 potentiostat. A platinum disc or graphite working electrode, a platinum wire auxiliary electrode and an aqueous saturated calomel reference electrode (SCE) were used in a three-electrode configuration. An RE $0089 \mathrm{X}-\mathrm{Y}$ recorder was used to trace the voltammograms. Electrochemical measurements were made under a dinitrogen atmosphere. All electrochemical data were collected at $298 \mathrm{~K}$ and are uncorrected for junction potentials.

\section{Crystallography}

Single crystals of $\left[\mathrm{Ru}\left(\mathrm{PPh}_{3}\right)_{2}\left(\mathrm{~L}^{2}\right) \mathrm{Cl}_{2}\right]$ were grown by slow diffusion of hexane into a dichloromethane solution of the complex. Selected crystal data and data collection parameters are given in Table 1. Data were collected on an Enraf-Nonius CAD-4 diffractometer using graphite-monochromated Mo-Ka radiation $(\lambda=0.71073 \AA)$. Three standard reflections measured every $3600 \mathrm{~s}$ of X-ray exposure showed no significant intensity variation over the course of data collection. X-Ray data reduction and structure solution and refinement were carried out using the NRCVAX package. ${ }^{5}$

CCDC reference number 186/1739.

See http://www.rsc.org/suppdata/dt/a9/a907021d/ for crystallographic files in .cif format.

\section{Results and discussion}

Reaction of the oximes ( $\mathrm{HL}-\mathrm{O})$ with $\left[\mathrm{Ru}\left(\mathrm{PPh}_{3}\right)_{3} \mathrm{Cl}_{2}\right]$ proceeded smoothly in refluxing ethanol to afford imine complexes of the type $\left[\mathrm{Ru}\left(\mathrm{PPh}_{3}\right)_{2}(\mathrm{~L}) \mathrm{Cl}_{2}\right]$ in good yields. Formation of the imine complexes has been authenticated by structural characterization of $\left[\mathrm{Ru}\left(\mathrm{PPh}_{3}\right)_{2}\left(\mathrm{~L}^{2}\right) \mathrm{Cl}_{2}\right]$. The structure is shown in Fig. 1

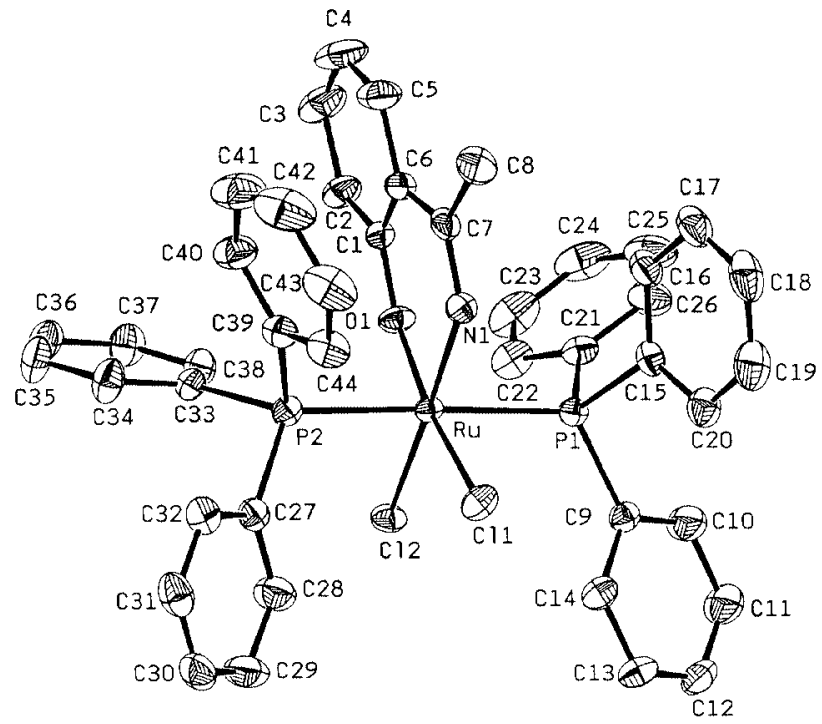

Fig. 1 View of the $\left[\mathrm{Ru}\left(\mathrm{PPh}_{3}\right)_{2}\left(\mathrm{~L}^{2}\right) \mathrm{Cl}_{2}\right]$ molecule.

and selected bond parameters are listed in Table 2. The oxime of 2-hydroxyacetophenone has lost the oxime oxygen and the resulting imine ligand is coordinated to ruthenium as a bidentate $\mathrm{N}, \mathrm{O}$-donor ligand, forming a six-membered chelate ring with a bite angle of $86.36^{\circ}$. The two $\mathrm{PPh}_{3}$ ligands are mutually trans, as is usually observed in complexes of ruthenium(III) containing the $\mathrm{Ru}\left(\mathrm{PPh}_{3}\right)_{2}$ moiety, ${ }^{6}$ and the two chloride ligands occupy mutually cis positions. The $\mathrm{NOP}_{2} \mathrm{Cl}_{2}$ coordination sphere around ruthenium is distorted octahedral in nature. The $\mathrm{Ru}-\mathrm{N}, \mathrm{Ru}-\mathrm{O}, \mathrm{Ru}-\mathrm{P}$ and $\mathrm{Ru}-\mathrm{Cl}$ bond lengths are all quite unremarkable, as are the phenolic $\mathrm{C}-\mathrm{O}$ and imine $\mathrm{C}-\mathrm{N}$ distances. $^{7}$ In view of the observed similarity in spectral and electrochemical properties (vide infra), the other two [Ru$\left(\mathrm{PPh}_{3}\right)_{2}(\mathrm{~L}) \mathrm{Cl}_{2}$ ] complexes are assumed to have a similar structure. The mechanism of this reaction is not yet clear. However, an oxygen from the oxime ligand is probably transferred to a $\mathrm{PPh}_{3}$, dissociated from $\left[\mathrm{Ru}\left(\mathrm{PPh}_{3}\right)_{3} \mathrm{Cl}_{2}\right]$. Indirect evidence for this oxo-transfer comes from detection of $\mathrm{OPPh}_{3}$ in the residue of the synthetic reactions (after isolation of [Ru$\left.\left.\left(\mathrm{PPh}_{3}\right)_{2}(\mathrm{~L}) \mathrm{Cl}_{2}\right]\right)$, identified by its characteristic infrared spectrum $\left(v_{\mathrm{P}-\mathrm{O}}\right.$ observed at $\left.1185 \mathrm{~cm}^{-1}\right)$. Triphenylphosphine is well known to act as an oxygen-scavenger in many oxo-transfer reactions. ${ }^{8}$ The role of $\left[\mathrm{Ru}\left(\mathrm{PPh}_{3}\right)_{3} \mathrm{Cl}_{2}\right]$ in this reaction is not yet clear, but that it does not act as a mere supplier of $\mathrm{PPh}_{3}$ is clear from the fact that a mixture of $\mathrm{PPh}_{3}$ and the oxime is unable to bring about an oxo-transfer reaction. Prior coordination of the oxime ligand to ruthenium, followed by oxo-transfer from the metal-bound ligand appears probable.

Infrared spectra of the $\left[\mathrm{Ru}\left(\mathrm{PPh}_{3}\right)_{2}(\mathrm{~L}) \mathrm{Cl}_{2}\right]$ complexes show strong vibrations near 520,695 and $740 \mathrm{~cm}^{-1}$, which are attributed to the $\mathrm{Ru}\left(\mathrm{PPh}_{3}\right)_{2}$ fragment. ${ }^{9}$ A sharp peak near $3300 \mathrm{~cm}^{-1}$ is consistent with the presence of an $\mathrm{N}-\mathrm{H}$ bond $^{10}$ in the coordinated imine fragment of the phenolate ligands. Two $v(\mathrm{Ru}-\mathrm{Cl})$ stretches are observed near 330 and $320 \mathrm{~cm}^{-1}$ due to the $c i s-\mathrm{RuCl}_{2}$ fragment. ${ }^{11}$ The $\left[\mathrm{Ru}\left(\mathrm{PPh}_{3}\right)_{2}(\mathrm{~L}) \mathrm{Cl}_{2}\right]$ complexes are soluble in polar organic solvents, such as dichloromethane, chloroform, acetonitrile, etc., producing intense green solutions. The electronic spectra of these complexes have been recorded in dichloromethane solution. Spectral data are presented in Table 3 and a representative UV-vis spectrum is shown in Fig. 2. Each complex shows a few very intense absorptions in the ultraviolet region, several intense absorptions in the visible region and a weak absorption in the nearIR region. The absorptions in the ultraviolet region are attributable to transitions occurring within the ligand orbitals. The intense absorptions observed in the visible region may be assigned to ligand-to-metal charge-transfer 


\begin{tabular}{|c|c|c|c|c|}
\hline \multirow[b]{2}{*}{ Compound } & \multirow[b]{2}{*}{$\mu_{\mathrm{eff}} / \mu_{\mathrm{B}}$} & \multirow{2}{*}{$\begin{array}{l}\text { Electronic spectral data }{ }^{a} \\
\lambda_{\max } / \mathrm{nm}\left(\varepsilon / \mathrm{M}^{-1} \mathrm{~cm}^{-1}\right)\end{array}$} & \multicolumn{2}{|c|}{$\begin{array}{l}\text { Cyclic voltammetric data }{ }^{a, b} \\
E_{1 / 2} / \mathrm{V}\left(\Delta E_{\mathrm{p}} / \mathrm{mV}\right)\end{array}$} \\
\hline & & & $\mathrm{Ru}^{\mathrm{III}}-\mathrm{Ru}^{\mathrm{IV}}$ & $R u^{\mathrm{III}}-\mathrm{Ru}^{\mathrm{II}}$ \\
\hline$\left[\mathrm{Ru}\left(\mathrm{PPh}_{3}\right)_{2}\left(\mathrm{~L}^{1}\right) \mathrm{Cl}_{2}\right]$ & 1.86 & $1745(21), 685(2200), 360^{c}(9300), 298(26100)$ & $1.15(70)$ & $-0.38^{d}$ \\
\hline$\left[\mathrm{Ru}\left(\mathrm{PPh}_{3}\right)_{2}\left(\mathrm{~L}^{2}\right) \mathrm{Cl}_{2}\right]$ & 1.91 & $1670(28), 672(1800), 350^{c}(8100), 297(23200)$ & $0.88(70)$ & $-0.41^{d}$ \\
\hline$\left[\mathrm{Ru}\left(\mathrm{PPh}_{3}\right)_{2}\left(\mathrm{~L}^{3}\right) \mathrm{Cl}_{2}\right]$ & 1.93 & $1740(34), 710(2300), 367^{c}(10000), 300(26600)$ & $0.90(70)$ & $-0.36^{d}$ \\
\hline
\end{tabular}

${ }^{a}$ In dichloromethane solution. ${ }^{b}$ Supporting electrolyte TBAP; reference electrode SCE; $E_{1 / 2}=0.5\left(E_{\mathrm{pa}}+E_{\mathrm{pc}}\right)$, where $E_{\mathrm{pa}}$ and $E_{\mathrm{pc}}$ are anodic and cathodic peak potentials, respectively; $\Delta E_{\mathrm{p}}=E_{\mathrm{pa}}-E_{\mathrm{pc}}$; scan rate $50 \mathrm{mV} \mathrm{s}{ }^{-1}$. ${ }^{c}$ Shoulder. ${ }^{d} E_{\mathrm{pc}}$ value.

Table 4 EPR $g$-values ${ }^{a}$ and derived parameters ${ }^{b}$ of the $\left[\mathrm{Ru}\left(\mathrm{PPh}_{3}\right)_{2}(\mathrm{~L}) \mathrm{Cl}_{2}\right]$ complexes

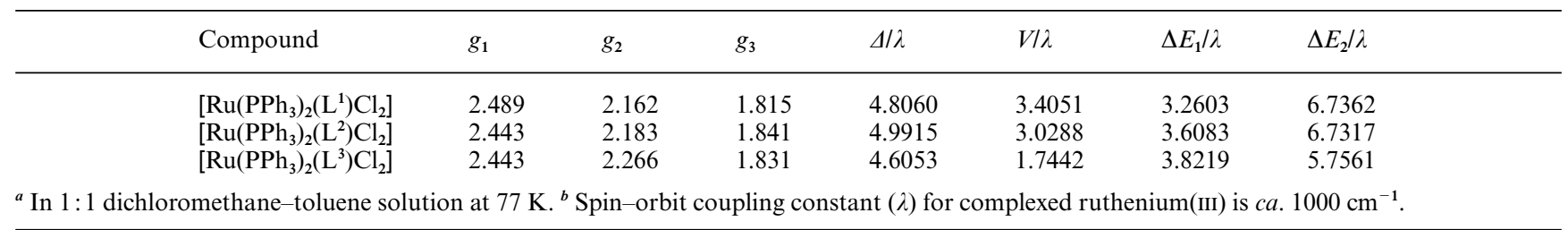

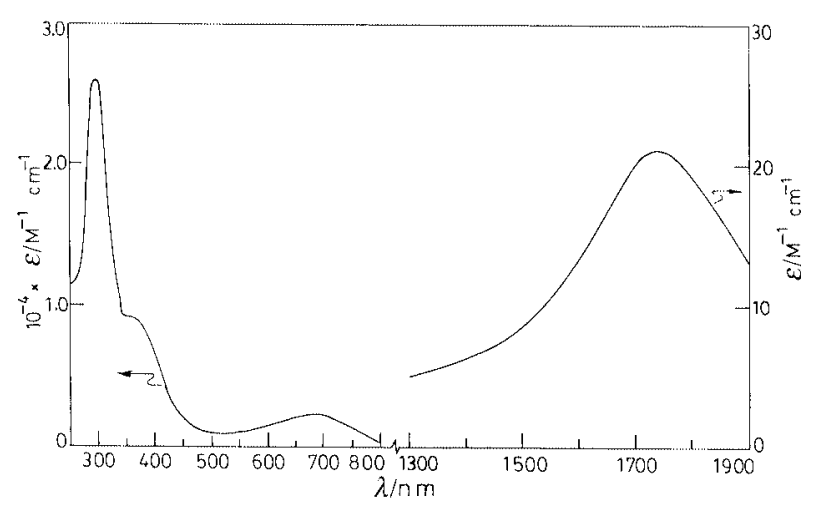

Fig. 2 Electronic spectrum of $\left[\mathrm{Ru}\left(\mathrm{PPh}_{3}\right)_{2}\left(\mathrm{~L}^{1}\right) \mathrm{Cl}_{2}\right]$ in dichloromethane solution.

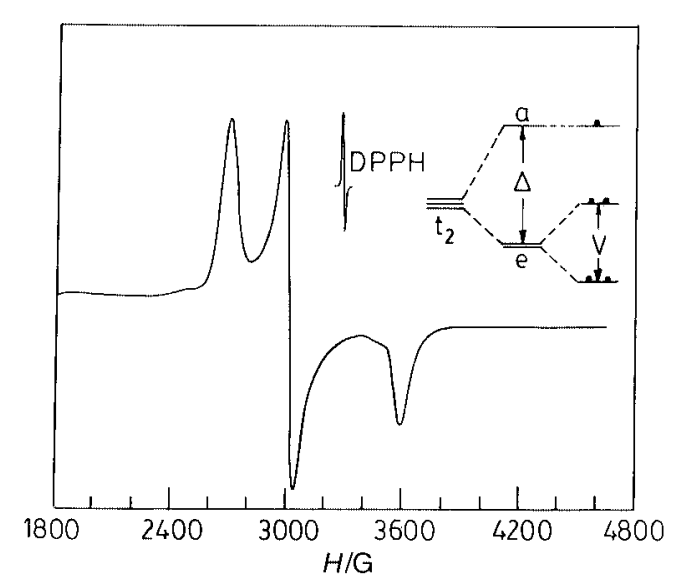

Fig. 3 EPR spectrum of $\left[\mathrm{Ru}\left(\mathrm{PPh}_{3}\right)_{2}\left(\mathrm{~L}^{3}\right) \mathrm{Cl}_{2}\right]$ in $1: 1$ dichloromethanetoluene solution at $77 \mathrm{~K}$.

transitions. The origin of the weak absorption in the near-IR region is discussed below.

Magnetic susceptibility measurements show that the [Ru$\left(\mathrm{PPh}_{3}\right)_{2}(\mathrm{~L}) \mathrm{Cl}_{2}$ ] complexes are one-electron paramagnetic (Table 3 ), which corresponds to the trivalent state of ruthenium (lowspin $\left.\mathrm{d}^{5}, S=\frac{1}{2}\right)$ in these complexes. Electron paramagnetic resonance $(\mathrm{EPR})$ spectra of the $\left[\mathrm{Ru}\left(\mathrm{PPh}_{3}\right)_{2}(\mathrm{~L}) \mathrm{Cl}_{2}\right]$ complexes, recorded in $1: 1$ dichloromethane-toluene solution at $77 \mathrm{~K}$, show rhombic spectra with three distinct signals $\left(g_{1}, g_{2}\right.$ and $g_{3}$, in decreasing order of magnitude). A representative spectrum is shown in Fig. 3 and the spectral data are presented in Table 4. The observed rhombicity of the EPR spectra is understandable

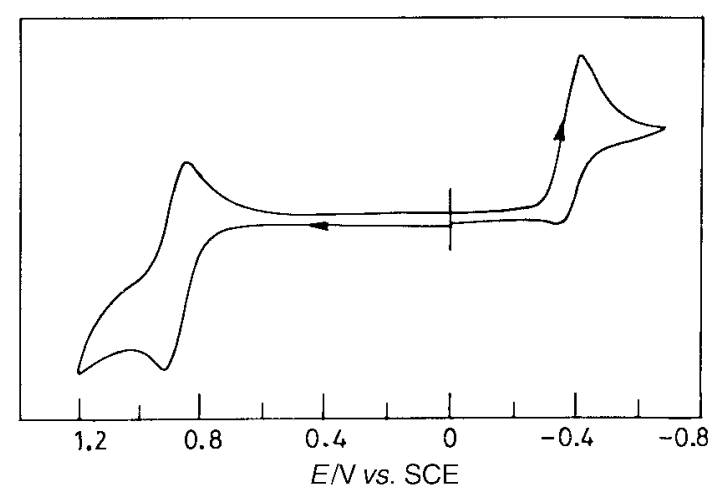

Fig. 4 Cyclic voltammograms of a $1.2 \times 10^{-3} \mathrm{M}$ solution of [Ru$\left.\left(\mathrm{PPh}_{3}\right)_{2}\left(\mathrm{~L}^{2}\right) \mathrm{Cl}_{2}\right]$ in dichloromethane $(0.1 \mathrm{M} \mathrm{TBAP})$ at a scan rate of $50 \mathrm{mV} \mathrm{s}^{-1}$.

in terms of the gross molecular symmetry of these complexes, containing the three non-equivalent $\mathrm{P}-\mathrm{Ru}-\mathrm{P}, \mathrm{O}-\mathrm{Ru}-\mathrm{Cl}$ and $\mathrm{N}-\mathrm{Ru}-\mathrm{Cl}$ axes. The rhombic distortion can be thought of as a combination of axial distortion ( $\Delta$, which splits $t_{2}$ into a and e) and rhombic distortion ( $V$, which splits e). The splitting pattern is illustrated in Fig. 3. Spin-orbit coupling causes further changes in the energy gaps. Thus two electronic transitions (transition energies $\Delta E_{1}$ and $\Delta E_{2} ; \Delta E_{1}<\Delta E_{2}$ ) are possible within these three levels. All these energy parameters have been computed (Table 4) using the observed $g$-values, the $g$-tensor theory of low-spin $\mathrm{d}^{5}$ complexes and a reported method. ${ }^{12}$ The axial distortion is observed to be much stronger than the rhombic. The $\Delta E_{1}$ transition falls in the infrared region (3200-3800 $\mathrm{cm}^{-1}$ ) and could not be detected. The $\Delta E_{2}$ transition, which is expected to occur near $6000 \mathrm{~cm}^{-1}(c a .1667 \mathrm{~nm})$, is indeed displayed by all three $\left[\mathrm{Ru}\left(\mathrm{PPh}_{3}\right)_{2}(\mathrm{~L}) \mathrm{Cl}_{2}\right]$ complexes as a weak absorption near the predicted energies (Tables 3 and 4). The EPR data analysis thus shows that the $\left[\mathrm{Ru}\left(\mathrm{PPh}_{3}\right)_{2}(\mathrm{~L}) \mathrm{Cl}_{2}\right]$ complexes are significantly distorted from ideal octahedral geometry, as observed in the crystal structure of $\left[\mathrm{Ru}\left(\mathrm{PPh}_{3}\right)_{2}\left(\mathrm{~L}^{2}\right) \mathrm{Cl}_{2}\right]$.

The electrochemical properties of the $\left[\mathrm{Ru}\left(\mathrm{PPh}_{3}\right)_{2}(\mathrm{~L}) \mathrm{Cl}_{2}\right]$ complexes have been studied in dichloromethane solution $(0.1$ M TBAP) by cyclic voltammetry. Voltammetric data are given in Table 3 and a representative voltammogram is displayed in Fig. 4. All three complexes show one oxidative response on the positive side of SCE and one reductive response on the negative side. The oxidation is assigned to ruthenium(III)-ruthenium(IV) oxidation. This oxidation is quasi-reversible in nature, characterized by a peak-to-peak separation $\left(\Delta E_{\mathrm{p}}\right)$ of $70 \mathrm{mV}$, and the cathodic peak current $\left(i_{\mathrm{pc}}\right)$ is lower than the anodic peak current 
$\left(i_{\mathrm{pa}}\right)$. The reductive response is irreversible and is assigned to ruthenium(III)-ruthenium(II) reduction. The one-electron nature of these responses has been confirmed by comparing their current heights with the standard ferrocene/ferrocenium couple under identical experimental conditions.

\section{Conclusion}

The present study shows an interesting oxo-transfer reaction mediated by $\left[\mathrm{Ru}\left(\mathrm{PPh}_{3}\right)_{3} \mathrm{Cl}_{2}\right]$. The applicability of $\left[\mathrm{Ru}\left(\mathrm{PPh}_{3}\right)_{3} \mathrm{Cl}_{2}\right]$ as a mediator to bring about oxo-transfer reactions from various oxygen-containing ligands is currently under investigation. The reactivity of the $c i s-\mathrm{RuCl}_{2}$ fragment of the $\left[\mathrm{Ru}\left(\mathrm{PPh}_{3}\right)_{3}(\mathrm{~L})-\right.$ $\mathrm{Cl}_{2}$ ] complexes is also being explored.

\section{Acknowledgements}

Financial assistance received from the Council of Scientific and Industrial Research, New Delhi [Grant No. 01(1408)/96/ EMR-II] is gratefully acknowledged. Thanks are also due to the Third World Academy of Sciences for financial support enabling the purchase of an electrochemical cell system.

\section{References}

1 C. Pearson and A. L. Beauchamp, Inorg. Chem., 1998, 37, 1242; T. Hashimoto, A. Endo, N. Nagao, G. P. Sato, K. Natrajan and K. Shimizu, Inorg. Chem., 1998, 37, 5211; P. Paul, B. Tyagi, A. K. Balikakhiya, M. M. Bhadbhade, E. Suresh and G. Ramachandraiah, Inorg. Chem., 1998, 37, 5733; J. Y. Lu, B. R. Cabrera, R. J. Wang and J. Li, Inorg. Chem., 1998, 37, 4480; E. V. RybakAkimova, A. Y. Nazarenko and S. S. Silchenko, Inorg. Chem., 1999, 38, 2974.
2 T. A. Stephenson and G. Wilkinson, J. Inorg. Nucl. Chem., 1966, 28, 945.

3 A. I. Vogel, A Text Book of Practical Organic Chemistry, ELBS, London, 1971, pp. 957-958.

4 (a) D. T. Sawyer and J. L. Roberts, Jr., Experimental Electrochemistry for Chemists, Wiley, New York, 1974, pp. 167-215; (b) M. Walter and L. Ramaley, Anal. Chem., 1973, 45, 165.

5 E. J. Gabe, Y. Le Page, J. P. Charland, F. L. Lee and P. S. White, J. Appl. Crystallogr., 1989, 22, 384.

6 S. Chattopadhyay, N. Bag, G. K. Lahiri and A. Chakravorty, J. Chem. Soc., Dalton Trans., 1990, 3389; S. Bhattacharya and C. G. Pierpont, Inorg. Chem., 1991, 30, 1511; M. Menon, A. Pramanik, N. Bag and A. Chakravorty, J. Chem. Soc., Dalton Trans., 1995, 1417.

7 K. Sui, S. M. Peng and S. Bhattacharya, Polyhedron, 1999, 18, 631; F. Basuli, A. K. Das, G. Mostafa, S. M. Peng and S. Bhattacharya, submitted for publication.

8 B. A. Moyer, B. K. Sipe and T. J. Meyer, Inorg. Chem., 1981, 20, 1475; M. E. Marmoin and K. J. Takeuchi, J. Am. Chem. Soc., 1988, 110, 1472; C. M. Che and K. Y. Yong, J. Chem. Soc., Dalton Trans., 1989, 2065.

9 S. Bhattacharya and C. G. Pierpont, Inorg. Chem., 1991, 30, 2906; N. C. Pramanik and S. Bhattacharya, Trans. Met. Chem., 1999, 24, 95.

10 J. R. Dyer, Application of Absorption Spectroscopy of Organic Compounds, Prentice-Hall of India Pvt. Ltd., New Delhi, 1989, 37.

11 S. Choudhury, M. Kakoti, A. K. Dev and S. Goswami, Polyhedron, 1992, 11, 3183

12 B. Bleany and M. C. M. O'Brien, Proc. Phys. Soc., London, Sect. B, 1956, 69, 1216; J. S. Griffith, The Theory of Transition Metal Ions, Cambridge University Press, London, 1961, p. 364; S. Bhattacharya and A. Chakravorty, Proc. Indian Acad. Sci., Chem. Sci., 1985, 95, 159.

Paper a907021d 